\title{
Assessment and Public Reporting of Geothermal Resources in Germany: Review and Outlook
}

\author{
Thorsten Agemar * (1D, Josef Weber and Inga S. Moeck \\ Leibniz Institute for Applied Geophysics, Stilleweg 2, D-30655 Hannover, Germany; \\ josef.weber@liag-hannover.de (J.W.); inga.moeck@liag-hannover.de (I.S.M.) \\ * Correspondence: thorsten.agemar@liag-hannover.de; Tel.: +49-(0)511-643-2937
}

Received: 8 December 2017; Accepted: 29 January 2018; Published: 2 February 2018

\begin{abstract}
Any geothermal resource assessment requires consistent and widely accepted terminology, methods, and reporting schemes that facilitate the comparison of geothermal resource estimates. This paper reviews common resource assessment methods, as well as reporting codes and terminology. Based on a rigorous analysis of the portrayed concepts and methods, it discusses the appropriateness of the existing reporting codes for sustainable utilization of geothermal resources in Germany. Since the last quantitative geothermal resource assessment in Germany was done 15 years ago, a revised report is overdue. Unlike fossil energy commodities, geothermal energy replenishes naturally and heat recuperation increases in created heat sinks. This replenishment process offers the opportunity for sustainable reservoir management in the case of moderate production rates or cyclic operation. Existing reporting codes, however, regard geothermal resources in a similar way to fossil resources or focus too much on field development rather than on the whole assessment process. In order to emphasize the renewability of geothermal energy, we propose the reporting of geothermal capacities (per doublet or per $\mathrm{km}^{2}$ ) instead of recoverable heat energy which depends very much on project lifetime and other factors. As a first step, a new classification scheme for geothermal resources and reserves is outlined.
\end{abstract}

Keywords: energy; doublet; sustainability; renewability; reporting code; probability; exploration risk

\section{Introduction}

The shift from fossil fuels to renewable energy plays an important part in the attempt of reducing greenhouse gas emissions. The required exit from fossil fuel supply is often reduced to electricity supply, although energy for heating covers a major part of the primary energy consumption. In Germany, approximately $54 \%$ of the primary energy consumption is spent for heating and hot water. The energy used for space heating and hot water reached a level of $780 \mathrm{TWh} / \mathrm{a}$ in 2015 [1]. In the same year, all German geothermal direct use facilities produced just 1 TWh of heat. Besides these direct use facilities, nine geothermal installations produce electricity from geothermal water $\left(>120^{\circ} \mathrm{C}\right)$, typically in combination with district heating. Unfortunately, no high enthalpy geothermal resources (with fluid temperatures greater than $200{ }^{\circ} \mathrm{C}$ ) are available in Germany. Among all German geothermal sites, the geothermal power plant at Insheim taps the hottest fluid with a temperature of $165{ }^{\circ} \mathrm{C}$. Geothermal energy utilization in Germany has increased by an annual growth rate of approximately $10 \%$ over the past six years. In 1992, the first geothermal power plant in Germany was built in the town Neustadt-Glewe (northern Germany), however with an installed capacity of a mere $210 \mathrm{~kW}_{\mathrm{e}}$. For comparison, recently commissioned geothermal power plants have installed capacities of several megawatts. Particularly, the region around Munich has benefitted from the rapid geothermal development in recent years. The Upper Jurassic carbonate rock of the north Alpine foreland basin has been the target of numerous geothermal drilling projects [2,3]. Regarding this development, it is 
clear that geothermal energy has a high potential in Germany. However, for project planners as well as for governments it is important to quantitatively assess the geothermal potential of a site or a region. Geothermal energy projects are subject to technological, geological, regulatory and economic constraints in a way that has significant parallels with fossil fuel projects. Considering local demands for heat supply with specific requirements in terms of temperature and capacity, the question arises if it is advisable to compare the cumulative geothermal energy output over project lifetime with the output of non-renewable energy sources (e.g., coal, gas etc.) where these requirements can be met in any case.

\section{Definition of Resources and Reserves and Previous Estimates}

Generally, geothermal potential is divided into geothermal resources and reserves. This widely accepted classification scheme has been adapted from oil and gas exploration. In their classical paper Muffler \& Cataldi [4] describe how to apply this scheme to geothermal energy. All of the geothermal energy in the Earth's crust beneath a specified area is formally termed the resource base. Residuals represent the accessible share of the resource base that may not be extracted economically and legally in the future. Resources are defined as the share of heat energy that can be exploited with the current technology. They are subdivided into economic, sub-economic and residual resources. Resources may be further subdivided in the order of decreasing uncertainty into undiscovered, inferred, indicated and measured resources (e.g., [4-6]). They might as well be categorized as low confidence, moderate confidence or high confidence estimates [7]. Reserves are defined as the share of the resources that are identified and exploitable economically under the current cost level. Proven reserves generally imply little or no further exploration because energy extraction has been demonstrated to be feasible under current financial and legal constraints. Probable reserves comprise that share of resources for which commercial production cannot be predicted with a high degree of confidence.

An alternative concept has been introduced by Keyser \& Kaltschmitt [8] who differentiate between theoretical, technical, economic, and exploitable potential of geothermal resources. The term theoretical potential could be regarded as equivalent to the above noted definition of the resource base. The term technical potential is similar to the common definition of resource, as it encompasses all occurrences that could be extracted legally with current technology. The economic potential is defined as the geothermal potential that could be exploited economically irrespective of tax regulations, subsidies or infrastructure constraints. Therefore, this definition is of interest on a national level but not on a business level. The exploitable potential encompasses all relevant technical and economic constraints. It is similar to the above noted definition of reserve.

Rybach [9] refers to similar potential categories (theoretical, technical, economic, sustainable and developable potential) related to the economic or feasibility value of a project at a certain development phase. Rybach [9] concludes, any geothermal reporting codes should state the type of potential following a corresponding template.

The identification of geothermal resources that have not yet been discovered is based on the certainty that existing reserves occur in specific geologic settings. Analogous to fossil or mineral resource terminology, the association of specific geologic settings with geothermal resources can be categorized as geothermal play types [10]. The idea of the geothermal play concept is: (I) to start the assessment process with data hence generic geological models that are generally available before appraisal drilling; and, (II) to provide a worldwide applicable criteria catalog to group geothermal systems according to the likelihood of discovery. Ultimately, the identification of a certain play type has implications for exploration and extraction strategies [11]. However, in geothermal exploration and development systematic guidelines for quantifying geothermal resources are still lacking.

\section{Reporting Standards and Project Lifetime}

A number of guidelines exist on the mandatory and optional contents of national reports on geothermal resources and reserves, like for instance the Australian reporting code [5] or the 
Canadian reporting code [6]. These guidelines cover the way exploration results, field observations and expected geothermal production are classified and publicly reported. The idea is to promote a standardized reporting scheme that enables investors, politicians, and consultants to compare resource and reserve figures of various regions or countries for decision making. The Australian and Canadian geothermal reporting codes build upon the International Reporting Template CRIRSCO (Committee for Mineral Reserves International Reporting Standards), which was first published in 2006 [12]. The United Nations Economic Commission for Europe (UNECE) [13] have proposed minimum standards on reporting geothermal resources and reserves that build upon the United Nations Framework Classification (UNFC) on fossil energy and mineral reserves and resources 2009. While the UNECE specifications [13] govern how geothermal resources are reported, guidelines still need to be developed for different steps in the assessment and quantification process.

All reporting codes classify resources in terms of uncertainty and socio-economic feasibility. However, the classification of the UNECE is more sophisticated as it represents a generic three-dimensional system. Here, the socio-economic feasibility is evaluated along the E-axis. This evaluation differentiates between commercial projects that rely on governmental subsidies, commercial projects that do not need governmental support, and projects that are not economically viable. Three E-categories are available:

$\mathrm{E} 1=$ economic viable under current market conditions

$\mathrm{E} 2$ = not yet economic viable under current market conditions but probably in the future

$\mathrm{E} 3=$ economic viability is unlikely for the future or cannot be estimated due to lack of data

The uncertainty dimension is split into two axes: the uncertainty about the technical feasibility (F-axis) and the uncertainty about the quantity (G-axis). Four F-categories are available:

$\mathrm{F} 1=$ feasibility confirmed

$\mathrm{F} 2$ = feasibility is subject to further evaluation

F3 = feasibility unconfirmed due to limited technical data

$\mathrm{F} 4=$ not feasible due to technological limitations and/or other constraints

The quantitative assessment is subdivided into four G-categories and should be based on a probability distribution (Table 1).

Table 1. Geologic uncertainty categories (G-axis definitions) of the United Nations Economic Commission for Europe (UNECE) geothermal resource classification.

\begin{tabular}{ccc}
\hline Energy Estimate & UNFC Class & Probabilistic Definition \\
\hline Low estimate/high confidence estimate & G1 & P90 \\
Best estimate/moderate confidence estimate & G2 & P50 minus P90 \\
High estimate/low confidence estimate & G3 & P10 minus P50 \\
Estimates based on indirect evidence & G4 & any of the above classes \\
\hline
\end{tabular}

On the basis of the UNECE specifications, it is possible to adequately include projects where extractable energy quantities are not precisely known. This could be the case when the size of the reservoir and/or the fluid recharge rate is not yet known, although current production is satisfactory. This quantitative part of the UNECE specifications differs from the CRIRSCO template where geothermal resources are subdivided into the categories "measured", "indicated" and "inferred" according to availability of data and geologic knowledge. Therefore, mapping of UNFC categories to the CRIRSCO scheme is never perfect (Table 2). 
Table 2. Mapping of CRIRSCO template to United Nations Framework Classification (UNFC)-2009 Classes and Categories (modified from UNECE 2013 [7]).

\begin{tabular}{cccccc}
\hline \multicolumn{2}{c}{ CRIRSCO Template } & \multicolumn{2}{c}{ UNFC-2009 Categories “Minimum” } & UNFC-2009 Class \\
\hline \multirow{2}{*}{ Reserve } & $\begin{array}{c}\text { Proved } \\
\text { Probable }\end{array}$ & E1 & F1 & G1 & Commercial Projects \\
\hline \multirow{2}{*}{ Resource } & $\begin{array}{c}\text { Measured } \\
\text { Indicated } \\
\text { Inferred }\end{array}$ & E2 & F2 & G1 & $\begin{array}{c}\text { Potentially } \\
\text { Commercial Projects }\end{array}$ \\
\hline \multicolumn{2}{c}{ Exploration Results } & E3 & F3 & G4 & Exploration Projects \\
\hline
\end{tabular}

Other principles are common to the Australian reporting code [5], the Canadian reporting code [6] and the UNECE reporting code [13]:

- $\quad$ The report should be written clearly without any ambiguities.

- $\quad$ The report should include all relevant information that are required to interpret the estimates.

- The report should be based on work of qualified and experienced persons who are members of recognized professional organizations.

- Recoverable geothermal energy resources should be reported in MW years or GW years. The share of geothermal energy that is converted to electricity should be estimated on the basis of the net energy output by applying appropriate conversion efficiency factors. Subscripts like "th" or "e" must be used to differentiate between thermal and electrical energy.

Thus, the reporting codes use classification schemes which have some principles in common but differ in other aspects. Generally, all reporting codes could be used for any region or country since they are not tailored to specific play types. From the expert perspective, detailed instructions on the way resource assessments should be conducted are missing in the reporting codes. The UNECE recommends the application of notional projects to resource assessment. An overview on relevant assessment methods will be given in the following chapter.

The geothermal reserve can be expressed as net energy extraction rate times remaining years of operation or as maximum annual production. According to the UNFC specifications, the minimum of economic limit, design life, contract period and entitlement period should be considered as project lifetime.

The economic limit may be the time when relevant subsidies run out or the expected energy extraction rate declines to a level that makes the project uneconomic (e.g., thermal breakthrough). In Germany, geothermal electricity benefits from guaranteed feed-in tariffs, which are $0.252 \mathrm{ct} / \mathrm{kWh}$ for 20 years from the beginning of the year after commissioning (as at 2017). This implies that current geothermal power plants are projected for an amortization period of 20 years but may exist beyond that period. Geothermal direct use projects may benefit from the governmental renewable energy incentive program (Marktanreizprogramm, MAP), last amended on 11 March 2015 [14]. Further subsidies exist for district heating networks that are fed by combined heat and power plants (Kraft-Wärmekopplungsgesetz, KWKG), last amended on 21 December 2015 [15].

The design life of a project reflects the durability of major components. Well drilling typically amounts to approximately $40 \%$ of total expenditures in Germany. Thus, the integrity lifetime of the well casing and cementing is an important issue.

The contract period for a geothermal project is the term of existing, or reasonably expected, sales contracts for geothermal energy commodities. It should cover at least the expected amortization period.

The entitlement for exploiting geothermal energy may be given for up to 50 years by governmental authorities in Germany, but extensions are possible. The entitlement comprises all rights necessary to produce hot water from the reservoir, create proprietorship of the extracted geothermal energy, and inject the cooled down water back to the reservoir. It is generally limited to a maximum pumping rate. 
Project lifetimes of more than 100 years are not unrealistic for deep, confined aquifers with re-injection or sufficient recharge, as is the case for most geothermal direct use facilities in Germany. But it is very difficult to estimate project lifetimes accurately because the expected amortization period is generally much shorter than the cooling time of the reservoir or the lifetime of the wells. Schulz and Jobmann [16] set 200 years for their doublet grid calculations as maximum project lifetime, although they noted that available resources could last much longer when pumping rates are low. In Germany, some deep wells $(>400 \mathrm{~m}$ ) proved to have a very long life, like for instance the saltern Luisenhall in Göttingen which produced brine for the past 150 years [17]. However, the durability of wells depends on several factors (e.g., strength of casing and cementing, subsurface stress field, active faults, fluid chemistry) and little long-term experience exists on the possible maximum lifetime of modern deep geothermal wells in Germany. The UNECE reporting code recommends splitting reserve estimates into several subsequent or additional projects. However, it remains difficult to apply mining and fossil fuel terminology to geothermal energy due to the fundamental difference that fossil reserves are finite and declining whereas geothermal energy is infinitely replenished.

\section{Geothermal Resources in Germany}

In Germany, direct use facilities dominate the geothermal energy market. Very few installations combine heat and power production $[2,18,19]$. Only three geothermal power plants operate without direct heat supply (Insheim, Dürnhaar and Kirchstockach). Geothermal facilities for district heating, thermal spas, and space heating account for an $88 \%$ share of the total deep geothermal energy production [2,18]. A trifling amount of geothermal heat is used for other direct use applications like greenhouse heating or food production. Recently, plans for brewing beer with geothermal heat came up in Bavaria. A higher demand from the food industry could help to expand the use of geothermal energy in Germany, because industrial energy demand is not subject to weather or seasons. In addition, more spas could be heated with geothermal energy instead of oil or gas. Table 3 gives an overview of temperature requirements for existing and future geothermal applications in Germany.

Table 3. Minimum temperatures for geothermal applications in Germany.

\begin{tabular}{cc}
\hline Minimum Temperature & Geothermal Heat Utilization \\
\hline $120{ }^{\circ} \mathrm{C}$ & Power Production \\
$50-120^{\circ} \mathrm{C}$ & Food Industry \\
$35-60{ }^{\circ} \mathrm{C}$ & Greenhouses \\
$60-90{ }^{\circ} \mathrm{C}$ & District Heating \\
$20-30{ }^{\circ} \mathrm{C}$ & Balneology, Space Heating (with or without heat pumps) \\
\hline
\end{tabular}

Generally, the estimation of geothermal resources must be based on minimum temperatures (cut-off temperature) below which operation is no longer feasible. Without a clear forecast of the future demand-side factors with regard to geothermal energy commodities, it is impossible to define a general cut-off temperature for a national resource assessment. Lower temperature requirements are met by more resources. Hence, a resource assessment on a project-by-project basis, as proposed by the UNECE [13], makes sense. Suchi et al. [20] mapped areas of thermal aquifers $\left(\geq 40^{\circ} \mathrm{C}\right)$ with inferred and proven geothermal potential in Germany (see also Figure 1). They categorized geothermal resources in terms of expected formation temperature. Although this study is rich in geologic details and covers almost all known resources related to deep aquifers in Germany, it does not quantify geothermal resources. The maps of this study and additional data and information on the geothermal potential of Germany are available to the public at https:/ / www.geoits.de (Geothermal Information System, GeotIS).

Different attempts have been made to quantify the various potentials of different geothermal resources in Germany. Keyser \& Kaltschmitt [8] estimated the "technical potential" of deep aquifers in Germany to be 55,000 $\mathrm{TWh}_{\text {th }}$. This estimate corresponds to "inferred resource" according to the above 
noted reporting codes. Paschen et al. [21] compiled data on the geothermal potential of hot aquifers, deep faults and the crystalline basement in Germany. According to their calculation, geothermal resources for power production amount to approximately 320,000 $\mathrm{TWh}_{\mathrm{e}}$. Another comprehensive estimate of German geothermal resources has been published by Hurter \& Hänel [22] in the European Geothermal Atlas. They reported 142,000 $\mathrm{TWh}_{\text {th }}$ of geothermal resources and $1900 \mathrm{TWh}_{\text {th }}$ of "probable geothermal reserves" for direct use. Unlike the study by Paschen et al. [21], Hurter \& Hänel [22] did not include the geothermal potential of deep faults and the crystalline basement. Only considering the geothermal resources related to deep aquifers, the heat-in-place estimate of Hurter \& Hänel [22] is 17\% higher than the corresponding estimate of Paschen et al. [21] and more than $2 \frac{1}{2}$ times the estimate of Keyser \& Kaltschmitt [8]. The discrepancies of these three studies demonstrate that the result of any resource estimate depends significantly on the methodology and the evaluated data. It is difficult to have confidence in the validity of geothermal resource assessments when widely different estimates are published. Another general question relates to the usefulness of any estimate that is completely disproportionate to current geothermal production of just $1.3 \mathrm{TWh}_{\text {th }}$ (direct use) per year [18].
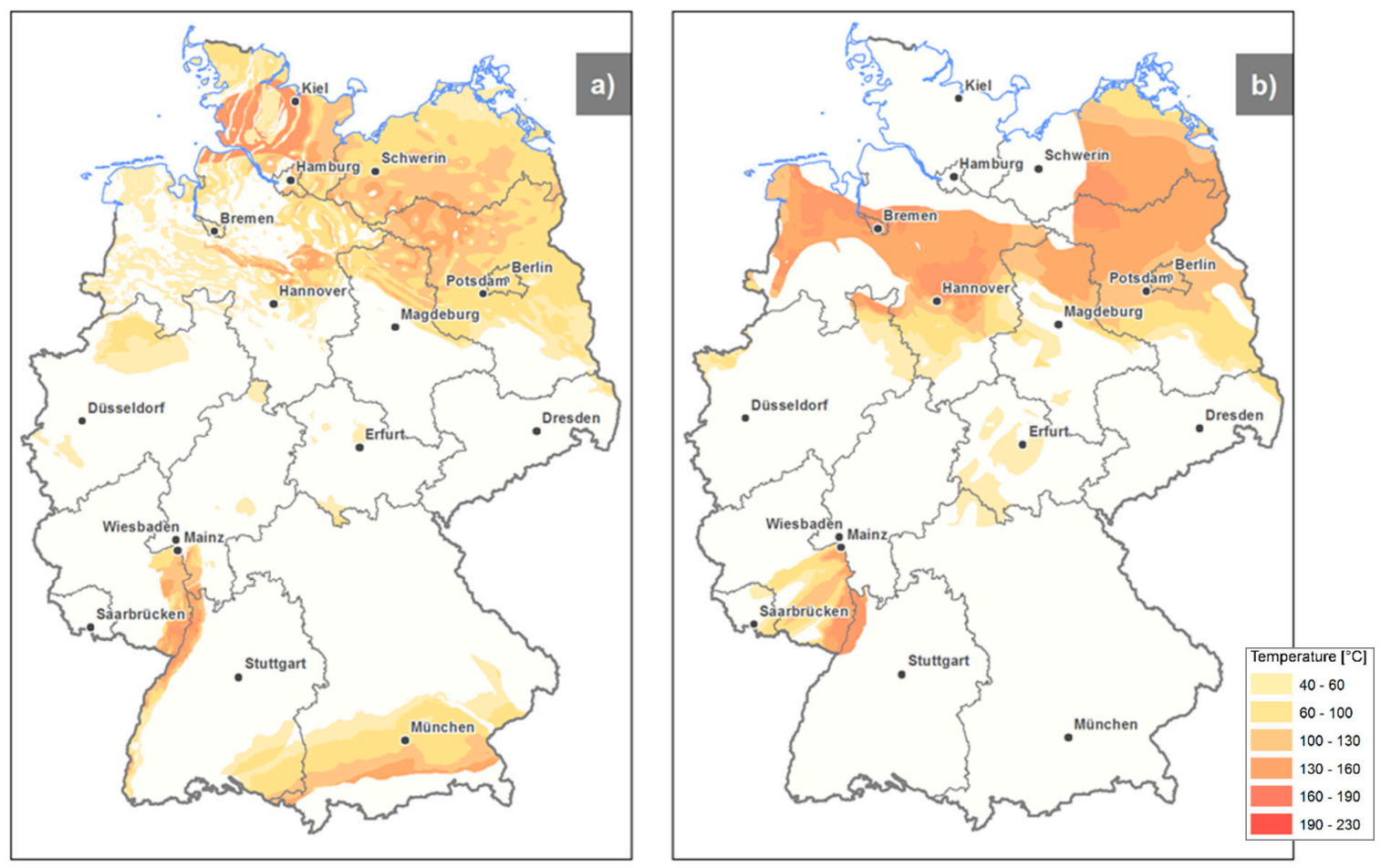

Figure 1. Maps of the Geothermal Atlas of Germany [20] for measured (a) and inferred/indicated (b) hydrothermal resources and associated maximum temperatures.

Today, GeotIS holds the largest and most comprehensive compilation of geologic data relevant for the assessment of geothermal resources and reserves $[18,19]$. Although it does not replace any location-specific prospectivity analysis, it provides preliminary figures on relevant parameters for determining the exploration risk: reservoir temperature and productivity. GeotIS also provides operation parameters and production records of geothermal facilities that could be used to estimate geothermal reserves [2].

\section{Resource Assessment Methods}

Muffler \& Cataldi [4] compiled four methods for geothermal resource assessment:

- Surface thermal flux (heat flow density);

- Heat in place; 
- Planar fracture method;

- Method of magmatic heat budget.

With the exception of the last method (magmatic heat budget) all these methods could be applied theoretically to geothermal resources in Germany. The second and third method appear to be the most appropriate approaches for geothermal resource assessment in Germany. Muffler \& Cataldi [4] rated the heat flow density method as not suitable for any quantitative estimate. Its use is limited to qualitative confirmation of the geothermal potential of convective hydrothermal systems with surface manifestations (e.g., hot springs). They deny its appropriateness for blind systems (geothermal resources without surface manifestations) which cover the majority of geothermal play types in Central Europe and possibly worldwide. In Germany, a resource estimate based only on heat flow density generally ignores the fact that the thermal regime of the subsurface changes with geothermal production which in turn affects the heat flow. It has been shown by Lavigne \& Maget [23] that at the end of operation the area of reservoir cooling is approximately one third of the rectangular area that encloses the production und injection well of a doublet. This area can be expressed as:

$$
A=\frac{2 d^{2}}{3}
$$

where $d$ is the distance between the two wells in the reservoir. In the Munich area, the average natural heat flux is approximately $75 \mathrm{~mW} / \mathrm{m}^{2}$. The geothermal heat stations and power plants in this area extract several tens of times to 500 times more heat energy than the natural surface heat flux. However, the geothermal facilities are expected to run for more than 50 years without any temperature decline at the production well [3], assuming steady production of geothermal energy. The Paris Basin, with more than 100 deep geothermal wells, offers a good opportunity to study the long term behavior of geothermal reservoirs in an intercratonic basin. More than 40 years of experience in geothermal energy production from Dogger aquifers exemplify that sustainable operation is possible. Only two doublets have been identified recently to show incipient temperature declines [24].

Apparently, a significant share of the withdrawn thermal energy gets replaced by heat conduction from rocks below, besides, and on top of the reservoir. This replacement is accelerated by the re-injection of cooled water because the heat flow is redirected towards the coolest part of the reservoir and proportional to the negative gradient in temperature (Fourier's law of heat conduction). Thus, the application of the heat flow density method is not appropriate for the estimation of geothermal resources in Germany.

The heat-in-place method (also known as volumetric method) has been widely used in the past decades for assessments on a variety of scales (e.g., [22,25-28]). It was first proposed by Bolton [29] and expanded by Nathenson [30] for the assessment of recoverable thermal energy in hydrothermal convection- and conduction-dominated systems. The first step of the heat-in-place approach is to identify the volume of interest. This is done by estimating the size, geometry and depth level of all relevant hydrogeological units. These units are then subdivided into several homogeneous compartment blocks each having a different temperature, porosity or lithology. Since nearly all geothermal resources in Germany are related to sediment systems, seismic surveys, well cuttings, well tests, well logs, and core samples contribute most to the required geologic knowledge. The next step is to calculate the stored energy $H_{0}$ in the rock matrix and fluid of each compartment:

$$
H_{0}=V \cdot\left[(1-\phi) \rho_{m} c_{m}+\phi \rho_{f} \mathcal{C}_{f}\right] \cdot\left(T_{r}-T_{o}\right)
$$

where $\rho_{m}$ and $\rho_{f}$ are the densities in $\mathrm{kg} / \mathrm{m}^{3}$ of the rock matrix and the fluid, $\phi$ is the dimensionless effective porosity, $c_{m}$ and $c_{f}$ are the specific heat capacities in $\mathrm{J} /(\mathrm{kg} \cdot \mathrm{K})$ of the rock matrix and fluid, respectively, $T_{r}$ is the mean temperature of the compartment and $T_{0}$ is the annual mean surface temperature. The calculation of the fraction of geothermal energy $H$ that is extractable from a volume of rock and fluid requires the introduction of an additional factor: 


$$
H=R \cdot H_{0}
$$

This recovery factor $R$ is required for the estimation of $H$. As aforementioned, for a doublet system the maximum fraction of the reservoir that is thermally affected by injection has been shown to be approximately one third [23]. This spatial limit of reservoir cooling and the injection temperature control the recovery factor $R$ :

$$
R=\frac{T_{r}-T_{\min }}{3\left(T_{r}-T_{o}\right)}
$$

here, $T_{\min }$ is either the injection temperature or any other temperature that marks an economic or technological limit. The scientific commission of the European Geothermal Atlas [22,31] recommended to use $25^{\circ} \mathrm{C}$ as $T_{\min }$. Such a low reference temperature yields estimates for the recoverable heat which are too optimistic. Also note that some geothermal fluids have high salt loads, which precludes cooling to very low temperatures. In order to avoid scaling in pipes, heat exchangers and other equipment in contact with the geothermal fluid, a re-injection temperature above $25^{\circ} \mathrm{C}$ might be required. Other authors argue that $T_{\min }$ should refer to the temperature below which the geothermal facility will be abandoned. Such an abandonment temperature depends on the utilization concept at a specific site and economic constraints. Anyway, the choice of $T_{\min }$ has a strong impact on the recovery factor and adds to the uncertainty of the resource estimate. As an alternative, the recovery factor can also be derived statistically from long production histories in geothermal fields. Based on data from geothermal fields in the United States with $75^{\circ} \mathrm{C}$ minimum (cut-off) temperature for Alaska and $95^{\circ} \mathrm{C}$ minimum (cut-off) temperature in the other states, Williams [32] proposes that the range for fracture-dominated geothermal reservoirs is from 0.08 to 0.20 , and for sediment-hosted reservoirs the range is from 0.10 to 0.25. Presumably, the reservoir type and the reservoir management also affect the recovery factor in a way that is difficult to predict. Another weakness is that the volumetric method does not take into account the replenishment of heat by conduction. The re-injection of the cooled fluid creates a heat sink in the reservoir. This causes temperature gradients which in turn generate inflow of heat. The thermal recuperation can make a huge difference when production rates are moderate and the reservoir is rather flat.

For Germany, the volumetric method can be applied to deep aquifers which represent the primary targets of current geothermal exploration. The prospects are generally good for estimating depth level, thickness and temperature of deep aquifers on the basis of existing maps and structural 3D models. Assumptions about the specific heat capacity can be made on the basis of expected lithology in the target formation. However, the economic feasibility also depends on the hydraulic conductivity which is difficult to assess prior to any well drilling and testing. Some geothermal well testing revealed insufficient productivity (or injectivity) for economic operation in Germany. Furthermore, deep aquifers used for geothermal energy extraction rarely exceed $50 \mathrm{~m}$ thickness. Hence, the replenishment of heat from layers above and below the aquifer by thermal conduction cannot be neglected. Therefore, the volumetric resource assessment could underestimate the project lifetime due to the possibility of a delayed thermal breakthrough.

The planar-fracture-method was first developed by Bödvarsson [33-35] for the assessment of geothermal energy extraction rates from fluid flowing through single fractures in hot basaltic rock. This concept has been adopted by other authors for estimating the heat extraction from hot-dry-rock systems which are commonly referred to as enhanced or engineered geothermal systems today (e.g., [36-38]). The planar-fracture-method assumes fluid flow through a simple rectangular gap between two homogeneous, isotropic, impermeable blocks of hot rock. Heat is transferred from the inside of the blocks to the fracture by thermal conduction and the fluid takes up the heat energy for further transport. Such simple reservoir models capture the essential features of thermal extraction, but real reservoirs usually consist of a network of fractures and the roughness and tortuosity of the rock-fluid-interface also affects fluid flow and heat extraction. The fluid flow conditions of real geothermal systems have been summarized by Björnsson \& Bödvarsson [39] who surveyed published 
data on geothermal power plants. Their results revealed that geothermal systems in which fluid flow is dominated by fractures require less porosity to achieve a given transmissivity than systems that are dominated by matrix porosity. Fracture porosity as low as $0.2 \%$ may still be sufficient for economic production.

The efficiency of heat extraction generally increases with decreasing fracture spacing in a geothermal system $[37,40,41]$. The highest thermal extraction efficiency can be expected for intergranular fluid flow in porous reservoirs due to the extremely large contact area between rock matrix and fluid as has been shown in various simulation models [40-42].

The efficiency of heat extraction determines the thermal output but equally important are the time scales of thermal recuperation. If production levels exceed the natural recharge of fluid or the thermal recuperation over long periods of time, the geothermal resources invariably decline. Natural recharge can be substituted by reinjection of geothermal fluid after heat extraction. This is common praxis in all German facilities that exploit deep groundwater since natural recharge is typically very low and many geothermal fluids have high salt loads which cannot be disposed to surface waters. Spas are an exception because reinjection of bath water is prohibited for sanitary reasons (possible contamination of shallow groundwater which serves as tap water). Mégel and Rybach [40] simulated a low temperature $\left(62{ }^{\circ} \mathrm{C}\right)$ geothermal doublet used for district heating and investigated the sustainability of the project. For geothermal energy utilization, sustainability means the ability of a geothermal system to sustain the production level over long times. Sustainable production of geothermal energy therefore secures the long-life-cycle of the geothermal system. By allowing for thermal recuperation after a period of thermal extraction, they concluded that the geothermal resource renews itself on a time scale comparable to the extraction period, if production levels are moderate. The thermal recuperation typically shows asymptotic behavior, being strong at the beginning and slowing down subsequently, with the original state being restored theoretically only after an infinite time. However, Mégel and Rybach [40] demonstrated with their numerical simulations that a sustainable heat farming is possible if the operation strategy consists of a sequence of several extraction and downtime periods (cyclic operation). Their simulation results also show that shorter production-recuperation cycles produce more thermal energy. However, economic and legal considerations could favor longer production periods in order to improve the return of investment.

Fox et al. [38] modelled production and recuperation cycles for an engineered (or enhanced) geothermal system (EGS) with multiple parallel fractures (1,3 and 5 fracture planes). The results also indicate that heat extraction efficiency increases with decreasing fracture spacing, shorter extraction periods and longer recuperation periods.

Numerical simulation is not only a fundamental instrument for the evaluation and optimization of different operating parameters and production scenarios but also for the assessment of the sustainability of geothermal energy utilization. If a national resource assessment should be based on notional projects, as has been recommended by the UNECE, geothermal field simulations with notional doublets could provide the required thermal energy output quantities. Schulz \& Jobmann [16] were the first who demonstrated the feasibility of such a notional-projects-method for the Upper Jurassic aquifer underneath the southern German Molasse basin (north Alpine foreland basin). They developed a model based on analytical solutions for geothermal doublets. The production and injection wells were located in a regular grid with a uniform distance of $1 \mathrm{~km}$. The input parameters included maps of the temperature, the hydraulic and thermal conductivity, and the storage capacity of the aquifer. They estimated a total of $53.6 \mathrm{EJ}\left(13,900 \mathrm{TWh}_{\text {th }}\right)$ as geothermal resources and $31.3 \mathrm{EJ}\left(8900 \mathrm{TWh}_{\text {th }}\right)$ as geothermal reserves based on a cut-off temperature of $30^{\circ} \mathrm{C}$. The thickness of the aquifer was assumed to be constant due to a lack of precise data. More recently, Dussel et al. [3] analyzed the results of a finite element simulation of the long-term thermal and hydraulic behavior of the Upper Jurassic aquifer in the Munich area. This area experienced a tremendous boom with currently 16 facilities tapping hot water from depths between 2.0 and $4.5 \mathrm{~km}$. This remarkable development was initiated by the announcement of the renewable energy law in 2000 (Erneuerbare Energien Gesetz) and the 
guaranteed feed-in tariffs for green electricity. Dussel et al. [3] used all available subsurface data and operating parameters of the year 2011 (13 geothermal plants, 28 wells, and a total flow rate of approximately $400 \mathrm{~L} / \mathrm{s}$ ) in order to assess the sustainability of existing and future geothermal projects in this area. According to a 50-years-simulation run, the hydraulic and thermal interference between adjacent geothermal facilities is very low. Only 7 out of 28 wells will experience a pressure change of more than one bar. No temperature decline was predicted at the production wells after 50 years. Any temperature decline at the end of the run was limited to the close vicinity of the injection wells. Hence, a reserve estimate in terms of total extractable energy requires much longer simulation runs which would allow forecasts of the project lifetime with a high degree of confidence.

\section{Data Acquisition and Probability Analysis}

A new geothermal resource assessment should be based on current subsurface knowledge and customary statistical and geostatistical methods. The Leibniz Institute for Applied Geophysics (LIAG) maintains the Geophysics Information System (FIS-Geophysik) which contains a large amount of subsurface temperature data, primarily from Germany [43,44]. Most temperature records originate from industry's oil and gas exploration and span a wide range of different qualities. FIS-Geophysik provides subsurface temperature data from more than 11,000 wells, most of them located in Germany. Access and further information on applied correction methods can be found in the Internet at http:/ / fis-geophysik.de.

Agemar et al. [45] used these subsurface temperature data and additional surface temperature data derived from meteorological observations to construct a 3D temperature model that extends from ground level to $5000 \mathrm{~m}$ below sea level for Germany. They applied 3D universal kriging to a subset of the data. The data selection for this subset was based on data quality and data density criteria. With universal kriging it is possible to accommodate the vertical trend in the data in the estimation process. It is the only method which takes the measured spatial variability into account. The spatial correlation of the parameter of interest can be approximated with a parametric function based on a semi-variogram. Another major advantage of kriging is the calculation of the uncertainty associated with the predicted values. This uncertainty can be expressed as confidence intervals analog to standard deviation. Assuming Gaussian normal distribution for the residual temperature, the kriging variance can be used to generate a probability density function (PDF) which could be used to find for instance the P50 or P90 estimate for the reservoir temperature.

Hydraulic data should be derived from well tests. Well logs and core samples provide additional information on aquifer thickness, permeability, and porosity. The productivity of deep wells tapping the same reservoir often shows a weak spatial correlation. Thus, a simple frequency analysis is general appropriate for generating a PDF. The cumulative probability $P$ of achieving a reference productivity with the next well to be drilled can be estimated on the basis of the cumulative frequency:

$$
P=\frac{\sum q_{i}}{N}
$$

where $N$ is the number of wells with available well tests, and $q \in[0,1]$. Wells with a productivity equal or higher than the reference value obtain the value 1 , and wells with a productivity lower than the reference value obtain 0 . It is also possible to introduce weighting factors due to geological reasons that indicate some kind of anisotropy within the geothermal field. Ganz \& Thomas [46] proposed technical weighting factors to differentiate between well test results of hydrocarbon and geothermal wells. They argue that for the assessment of the probability of success (POS) today's geothermal wells are better indicators of reservoir transmissivity because geothermal wells are drilled with larger diameter and a longer section of the (deviated) well path typically intersects the reservoir. Such technical or geologic weighting factors are appropriate and can be included into the above equation:

$$
P=\frac{\sum w_{i} q_{i}}{\sum w_{i}}
$$


Here, $w_{i}$ is the weighting factor for each well. However, it is absolutely not allowed to discard dry wells or change cumulated frequencies by applying weighting factors to single value intervals. The application of weighting factors always bears the risk of introducing a bias to the probability estimate. An inverse distance weighting factor may be applied in the case of proven spatial continuity which is usually not the case, even for the hydraulic conductivity of porous sandstone aquifers. However, instead of relating weights to the reciprocal of the distance, it would be better to derive weights from a covariance function or semi-variogram, which characterizes the spatial variability of the residual component.

The logarithm of hydraulic conductivity data from geothermal reservoirs often shows a normal distribution with a negative skew whereas subsurface temperature data shows a normal distribution with a small positive skew. This is not surprising because extremely high hydraulic conductivities or extremely low temperatures are rare for geologic and physical reasons. Maps of the hydraulic conductivity of selected formations in Germany have been developed by Kuder [47], Kunkel et al. [48] and Birner [49] for the Geothermal Information System GeotIS (https: / www.geotis.de).

The probability of achieving a productivity equal or larger than the reference productivity and a temperature equal or larger than the reference temperature can be calculated as the product of the individual probabilities. For the assessment of resources or reserves, the PDF of the net output (heat or electricity) is more relevant than any PDF of a single subsurface parameter. The gross thermal output $P$ is given by:

$$
P=\dot{m} c\left(T_{p}-T_{i}\right)
$$

where $\dot{m}$ is the mass flow, $c$ is the specific heat capacity of the geothermal fluid, $T_{p}$ and $T_{i}$ are the temperatures of the produced and injected fluid, respectively. From this formula it becomes obvious that a higher reservoir temperature may compensate a lower mass flow (and vice versa) to some extent. The net output is the gross output minus any internal load and transmission loss. The PDF of the net output can be generated using Monte Carlo simulations with single parameter PDFs and conversion factors as input parameters. This way, all possible combinations of different hydraulic conductivities, temperatures and resulting conversion factors can be considered. The Monte Carlo technique has been applied to geothermal resource and reserve estimates in various geological settings. 10,000 trials are industry standard although a few thousand might be sufficient. Williams et al. [27], for instance, calculated the geothermal resources of the western part of the United States on the basis of Monte Carlo simulations. They defined statistical distributions for reservoir sizes, heat contents, and recovery factors for all geothermal fields and then used that data to estimate the amount of electrical power that could be generated. For the temperature and reservoir size, they assumed that the distributions were triangular, peaking at a most likely value and then declining linearly to either side of that value for liquid-dominated geothermal systems. For the recovery factors it was assumed that the probability of a particular value was the same throughout the possible range of values. A problem is that a rectangular probability distribution is a simplification of the reality and may result in the appearance of greater certainty than is justified. The Monte Carlo simulations were carried out for many sites in the western part of the Unites States. The results of this assessment by Williams et al. [27] show the potential contribution geothermal energy could make for electric power production in the United States in the future.

\section{Results and Discussion}

In Germany, the most important geologic settings for geothermal energy production are the South German Molasse Basin, the Upper Rhine Graben and the North German Basin. Other sedimentary basins also have some considerable geothermal potential, like for instance the Saar-Nahe Basin or the Thuringian Basin. The largest share of relevant data comprises borehole data and seismic data from oil and gas exploration. The data generally show a good coverage as can be seen in the Geothermal Information System GeotIS. Although much of this data is rather old and has been generated for a different purpose it is usually of acceptable quality and can be used for geothermal resource assessment. 
Unexplored subsurface regions are generally limited to areas with no hydrocarbon resources and deep crystalline basement rock volumes that could be used for enhanced/engineered geothermal systems (EGS).

Evaluation and mapping of geothermal resources could be done on the basis of the available data. Of primary concern are generally three aspects: technical and legal feasibility, commerciality, and sustainability. All these aspects can be investigated in the workflow outlined in Figure 2. Probabilistic techniques like Kriging and Monte Carlo simulation are considered to be extremely useful in this context. The focus of such a mapping project would be heat production rather than the generation of electric power because only very few geothermal facilities generate revenues exclusively from power production. Instead of estimating the total amount of extractable energy based on uncertain recovery factors it seems more appropriate to estimate capacities per doublet because project lifetime estimates are very often loosely constrained, ranging from the initial license period to 100 or more years. Thus, any resource mapping should not rely on project lifetimes. In addition, expected capacity and temperature are much more relevant for investment decisions than total energy production over time.

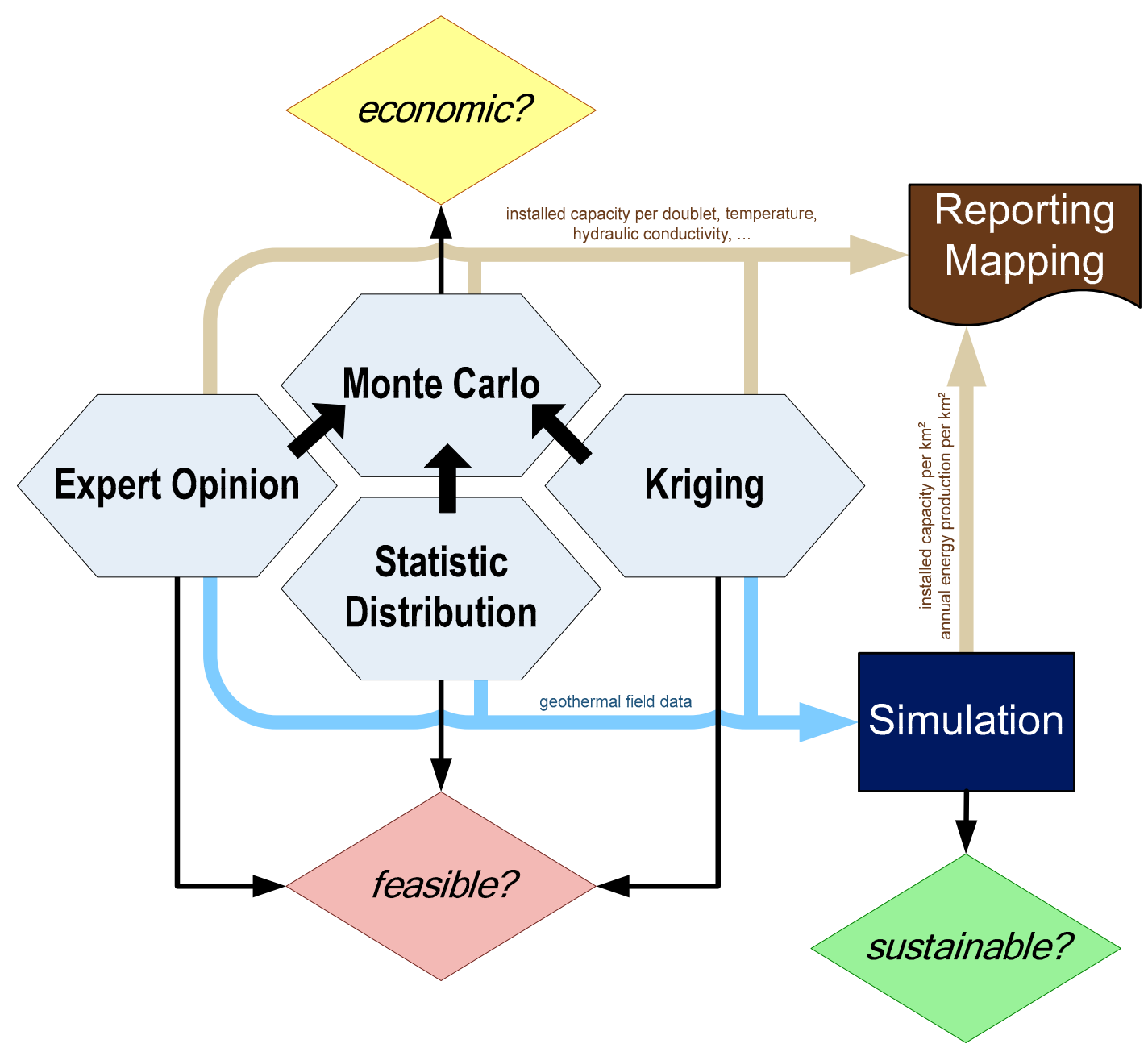

Figure 2. Statistic tools, methods, criteria, and workflows for geothermal resource and reserve assessment in Germany. Starting points are predictions of relevant parameters based on available data (pale blue hexagons). Expert opinion and Monte Carlo simulations can be used for mapping. Simulation models can be conducted for assessing output over time of single sites.

Nevertheless, the expected project lifetimes and the absence of major interferences with other geothermal facilities should be confirmed by analytical or numeric simulations during project 
development. In the case of a cyclic operation scenario the capacity forecast must be averaged over the production and the downtime period. The distance between production well, injection well and neighbor doublets must be large enough to ensure sustainable operation. This way, the optimal doublet density for a given geothermal reservoir can be found and the potential capacity per $\mathrm{km}^{2}$ can be computed. Furthermore, a resource assessment in terms of capacity per doublet or capacity per $\mathrm{km}^{2}$ is more satisfactory to investors, project planners, and capital markets than total recoverable heat energy. It is also more appropriate for a renewable energy source.

A geothermal reporting code covers the way geothermal resource and reserve assessments are classified and publicly reported. It does not cover the way assessments are made. The advantage of using a reporting code is to have comparable reports for different geothermal plays. Generally, the reporting codes presented are applicable to every region or country with geothermal resources (including Germany). However, the requirements by the German market and the existing data infrastructure ask for an independent reporting code. An attempt has been made to combine the advantages of the existing reporting codes. The resulting classification scheme outlined in Table 4 could mark the starting point for a discussion towards a new geothermal reporting code that considers geothermal capacities rather than recoverable heat in place. Such a capacity-oriented reporting code is more suitable for Germany but also for other countries like for instance the Netherlands or Poland which have a lot of relevant subsurface data. In contrast, estimates of recoverable heat in place tend to be very imprecise and have little meaning for decision makers.

The classification in Table 4 is a synthesis of the Australian, Canadian and UNECE reporting codes. The categories "Inferred", "Indicated" and "Measured" have been replaced by "High Estimate", "Best Estimate", and "Low Estimate" and include all resources that can be utilized with current or future technology and prevailing or more favorable market conditions and subsidies. These categories relate to computed probabilities P10, P50 and P90. Accordingly, resource estimates are computed on the basis of probability distributions. These categories represent unlike the UNECE classes G1, G2, and G3 cumulative quantities (see Table 1 for comparison). We believe that P10, P50 and P90 estimates are easier to understand than P50 minus P90 or P10 minus P50 as proposed by the UNECE [7]. Any resource estimates according to this new classification should relate to a reference injection temperature based on a realistic utilization scenario. A resource estimate for district heating, for instance, should match the potential demand side because heat cannot be transported over long distances. Thus, geothermal resources suitable for district heating must be matched with residential areas. Proved reserves should relate to facilities in operation or recently built facilities that are expected to start operation soon. The productivity estimate should relate to maximum permitted productivity (water legislation). Probable reserves are resources that could be utilized in commercial geothermal systems under current market conditions (e.g., interest rates, access to infrastructure, investments costs etc.) with existing technology and in agreement with environmental, social, legal, and regulatory requirements.

The following points summarize the conclusions of this paper:

- Geothermal heat production has a great potential for the future and could contribute significantly to the reduction of greenhouse gas emissions in Germany. The installed capacities in Germany are very low in relation to available resources.

- The last quantitative geothermal resource assessment for Germany is more than 15 years old. A revised report is overdue.

- Production of geothermal heat from a reservoir decreases its heat content, but also increases the natural recuperation rate. Sustainable production can be established for moderate production rates or cyclic operation. The timeframe is subordinate to more relevant parameters like capacity and temperature, as long as the return of investment is ensured.

- Unlike fossil energy commodities, geothermal energy is renewable but sustainability depends on the stored heat and heat extraction. The existing reporting codes have been developed on the basis of reporting codes for mining and neglect the replenishment of geothermal resources. 
Although complete replenishment may take infinite time, practical replenishment can be reached relatively early for geothermal facilities with low or moderate production rates, generally on a time-scale of the same order as the lifetimes of geothermal production systems. In order to ensure sustainable resource estimates, doublet density should be computed with analytical or numerical simulation tools.

- A new reporting code for geothermal energy is needed that emphasizes the renewable nature of geothermal energy and requests reporting of geothermal capacities per doublet or per $\mathrm{km}^{2}$ instead of recoverable heat in place. Any reporting of geothermal capacities according to a new reporting code would also require specific guidelines for resource assessment.

- Resource assessment should be based on all relevant subsurface data. It is highly recommended to apply probabilistic techniques like Monte Carlo simulations, Kriging, and other statistic tools.

- Injection temperature is a crucial parameter for any geothermal resource assessment and must be part of any resource report. In some cases it might be reasonable to compute more than one resource estimate for different utilization scenarios and injection temperatures.

Table 4. Summary of capacity oriented resources and reserves classification.

\begin{tabular}{|c|c|c|c|c|c|c|}
\hline \multicolumn{2}{|c|}{ Category } & \multirow{2}{*}{$\begin{array}{l}\text { Commerciality } \\
\text { Commercial } \\
\text { production can be } \\
\text { expected for the stated } \\
\text { lifetime }\end{array}$} & \multirow{2}{*}{$\begin{array}{l}\text { Definition } \\
\text { In operation or new facility } \\
\text { prior commissioning }\end{array}$} & \multirow{2}{*}{$\begin{array}{l}p \text {-Value } \\
\text { Does } \\
\text { not } \\
\text { apply }\end{array}$} & \multirow{2}{*}{$\begin{array}{l}\text { Required } \\
\text { Wellhead and injection } \\
\text { temperature }\left(T_{p}+T_{i}\right) \text {. Installed } \\
\text { geothermal capacity with } \\
\text { proof of sustainability. }\end{array}$} & \multirow{2}{*}{$\begin{array}{l}\text { Units } \\
{ }^{\circ} \mathrm{C} \\
\text { MWth } \\
\text { MWe (opt.) }\end{array}$} \\
\hline & $\begin{array}{l}\vec{J} \\
\stackrel{d}{0} \\
0\end{array}$ & & & & & \\
\hline 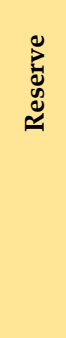 & $\begin{array}{l}\frac{0}{0} \\
\frac{1}{0} \\
0 \\
0\end{array}$ & $\begin{array}{l}\text { Feasible with existing } \\
\text { technology, prevailing } \\
\text { market conditions, and } \\
\text { available subsidies. } \\
\text { Huge chance of } \\
\text { economic viability. }\end{array}$ & $\begin{array}{l}\text { Not yet utilized geothermal } \\
\text { resource. Estimate based on } \\
\text { notional or planned projects. } \\
\text { Sufficient seismic and well } \\
\text { test data to characterize } \\
\text { temperature, transmissivity } \\
\text { and reservoir size. } \\
\text { Acceptable confidence about } \\
\text { fluid chemistry. }\end{array}$ & P50 & $\begin{array}{l}\text { Predicted wellhead and } \\
\text { injection temperature } \\
\left(T_{p}+T_{i}\right) \text {. Capacity estimates } \\
\text { for new doublets near existing } \\
\text { geothermal facilities or } \\
\text { existing facilities without } \\
\text { proof of sustainability. }\end{array}$ & $\begin{array}{l}{ }^{\circ} \mathrm{C} \\
\mathrm{MW}_{\text {th }} \\
\text { MWe (opt.) }\end{array}$ \\
\hline \multirow{3}{*}{ 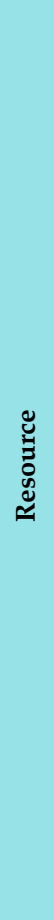 } & 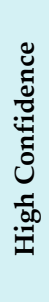 & \multirow{3}{*}{$\begin{array}{l}\text { Feasible with current or } \\
\text { future technology and } \\
\text { prevailing or more } \\
\text { favorable market } \\
\text { conditions or subsidies }\end{array}$} & $\begin{array}{l}\text { Low estimate. } \\
\text { Sufficient data to } \\
\text { characterize temperature } \\
\text { and reservoir size. Indicators } \\
\text { for hydraulic conductivity } \\
\text { (e.g., well logs, cuttings, core } \\
\text { samples, outcrop analogues } \\
\text { etc.) and fluid chemistry. }\end{array}$ & P90 & $\begin{array}{l}\text { Predicted reservoir } \\
\text { temperatures and utilization } \\
\text { scenarios with reasonable } \\
\text { injection temperatures. } \\
\text { Estimate of geothermal } \\
\text { capacity per doublet. } \\
\text { Optional: potential capacity } \\
\text { per } \mathrm{km}^{2} \text {. }\end{array}$ & $\begin{array}{l}{ }^{\circ} \mathrm{C} \\
\mathrm{MW}_{\text {th }} \\
\text { MWe (opt.) }\end{array}$ \\
\hline & 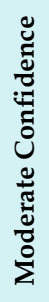 & & $\begin{array}{l}\text { Best estimate. } \\
\text { Sufficient data to } \\
\text { characterize temperature } \\
\text { and reservoir size. Indicators } \\
\text { for hydraulic conductivity } \\
\text { (e.g., well logs, cuttings, core } \\
\text { samples, outcrop analogues } \\
\text { etc.) and fluid chemistry. }\end{array}$ & P50 & $\begin{array}{l}\text { Predicted reservoir } \\
\text { temperatures and utilization } \\
\text { scenarios with reasonable } \\
\text { injection temperatures. Best } \\
\text { estimate of geothermal } \\
\text { capacity per doublet. } \\
\text { Optional: potential capacity } \\
\text { per } \mathrm{km}^{2} \text {. }\end{array}$ & $\begin{array}{l}{ }^{\circ} \mathrm{C} \\
\mathrm{MW}_{\text {th }} \\
\text { MWe (opt.) }\end{array}$ \\
\hline & 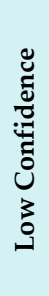 & & $\begin{array}{l}\text { High estimate. } \\
\text { Sufficient data to } \\
\text { characterize temperature } \\
\text { and reservoir size. Indicators } \\
\text { for hydraulic conductivity } \\
\text { (e.g., well logs, cuttings, core } \\
\text { samples, outcrop analogues } \\
\text { etc.) and fluid chemistry. }\end{array}$ & P10 & $\begin{array}{l}\text { Predicted reservoir } \\
\text { temperatures and utilization } \\
\text { scenarios with reasonable } \\
\text { injection temperatures. } \\
\text { Estimate of geothermal } \\
\text { capacity per doublet. } \\
\text { Optional: potential capacity } \\
\text { per } \mathrm{km}^{2} \text {. }\end{array}$ & $\begin{array}{l}{ }^{\circ} \mathrm{C} \\
\mathrm{MW}_{\text {th }} \\
\text { MWe (opt.) }\end{array}$ \\
\hline
\end{tabular}


Acknowledgments: We gratefully acknowledge the support of the Federal Ministry for Economic Affairs and Energy under Grant Number 0324025A.

Author Contributions: Thorsten Agemar outlined the concept and wrote this paper. Inga S. Moeck and Josef Weber have substantively revised and supplemented this paper.

Conflicts of Interest: The authors declare no conflict of interest.

\section{References}

1. Bundesministerium für Wirtschaft und Energie (BMWi). Energiedaten: Gesamtausgabe—Stand: Oktober 2017; BMWi: Berlin, Germany, 2017. Available online: https:/ /www.bmwi.de/Redaktion/DE/Artikel/Energie/ energiedaten-gesamtausgabe.html (accessed on 10 November 2017).

2. Agemar, T.; Weber, J.; Schulz, R. Deep Geothermal Energy Production in Germany. Energies 2014, 7, 4397-4416. [CrossRef]

3. Dussel, M.; Lüschen, E.; Thomas, R.; Agemar, T.; Fritzer, T.; Sieblitz, S.; Huber, B.; Birner, J.; Schulz, R. Forecast for thermal water use from Upper Jurassic carbonates in the Munich region (south German Molasse Basin). Geothermics 2016, 60, 13-30. [CrossRef]

4. Muffler, P.; Cataldi, R. Methods for Regional Assessment of Geothermal Resources. Geothermics 1978, 7, 53-89. [CrossRef]

5. Australian Geothermal Reporting Code Committee (AGRCC). Australian Code for Reporting of Exploration Results, Geothermal Resources and Geothermal Reserves: The Geothermal Reporting Code, 2nd ed.; Australian Geothermal Energy Group (AGEG): Adelaide, Australia, 2010.

6. Canadian Geothermal Code Committee (CGCC). The Canadian Geothermal Code for Public Reporting: Reporting of Exploration Results, Geothermal Resources and Geothermal Reserves; The Canadian Geothermal Energy Association (CanGEA): Calgary, AB, Canada, 2010.

7. United Nations Economic Commission for Europe (UNECE). United Nations Framework Classification for Fossil Energy and Mineral Reserves and Resources 2009 Incorporating Specifications for Its Application; United Nations: New York, NY, USA; Geneva, Switzerland, 2013.

8. Keyser, M.; Kaltschmitt, M. Potentiale hydrothermaler Erdwärme in Deutschland. In Angebotspotential der Erdwärme Sowie Rechtliche und Wirtschaftliche Aspekte der Nutzung Hydrothermaler Ressourcen; Geothermie Report 98-1, STR98/09. 8-26; GFZ Potsdam: Potsdam, Germany, 1998.

9. Rybach, L. The Future of Geothermal Energy and Its Challenges. In Proceedings of the World Geothermal Congress, Bali, Indonesia, 25-29 April 2010.

10. Moeck, I. Catalogue of geothermal play types based on geologic controls. Renew. Sustain. Energy Rev. 2014, 37, 867-882. [CrossRef]

11. Moeck, I.; Beardsmore, G.; Harvey, C.C. Cataloging Worldwide Developed Geothermal Systems by Geothermal Play Type. In Proceedings of the World Geothermal Congress, Melbourne, Australia, 19-25 April 2015.

12. Committee for Mineral Reserves International Reporting Standards (CMRIRS). CRIRSCO International Reporting Template: International Reporting Template for the Public Reporting of Exploration Results, Mineral Resources and Mineral Reserves. CRIRSCO, 2006. Available online: http://www.crirsco.com/ template.asp (accessed on 30 January 2018).

13. United Nations Economic Commission for Europe (UNECE). Specifications for the Application of the United Nations Framework Classification for Fossil Energy and Mineral Reserves and Resources 2009 (UNFC-2009) to Geothermal Energy Resources; United Nations: Geneva, Switzerland, 2016.

14. Bundesministerium für Wirtschaft und Energie (BMWi). Richtlinien zur Förderung von Maßnahmen zur Nutzung erneuerbarer Energien im Wärmemarkt; BMWi: Berlin, Germany, 2015.

15. Bundesministerium für Wirtschaft und Energie (BMWi). Kraft-Wärme-Kopplungsgesetz; BMWi: Berlin, Germany, 2015.

16. Schulz, R.; Jobmann, M. Hydrogeothermische Energiebilanz und Grundwasserhaushalt des Malmkarstes im Süddeutschen Molassebecken, Teilgebiet: Hydrogeothermik; Final Report, Archive Number 105040; Institut für Geowissenschaftliche Gemeinschaftsaufgaben (GGA): Hannover, Germany, 1989.

17. Steinert, A. Konzepte der Musealisierung von Technik und Arbeit: Museale Erschließung—Perspektive für das Industriedenkmal Saline Luisenhall; Peter Lang GmbH.: Bern, Switzerland, 1997. 
18. Leibniz Institute for Applied Geophysics (LIAG). The Geothermal Information System GeotIS. Available online: https: / /www.geotis.de (accessed on 10 November 2017).

19. Agemar, T.; Alten, J.; Ganz, B.; Kuder, J.; Kühne, K.; Schumacher, S.; Schulz, R. The Geothermal Information System for Germany-GeotIS. Z. Dtsch. Ges. Geowiss. 2014, 165, 129-144. [CrossRef]

20. Suchi, E.; Dittmann, J.; Knopf, S.; Müller, C.; Schulz, R. Geothermie-Atlas zur Darstellung möglicher Nutzungskonkurrenzen zwischen $\mathrm{CO}_{2}$-Einlagerung (CCS) und Tiefer Geothermie in Deutschland. Zeitschrift der Deutschen Gesellschaft für Geowissenschaften (Ger. J. Geol.) 2014, 165, 439-453. [CrossRef]

21. Paschen, H.; Oertel, D.; Grünwald, R. Möglichkeiten der Geothermischen Stromerzeugung in DeutschlandSachstandsbericht; Arbeitsbericht 84; Büro für Technikfolgen-Abschätzung Beim Deutschen Bundestag: Berlin, Germany, 2003.

22. Hurter, S.; Hänel, R. (Eds.) Atlas of Geothermal Resources in Europe; Office for Official Publications of the European Communities: Luxembourg, 2002.

23. Lavigne, J.; Maget, P. Les Ressources Géothermiques Française-Possibilités de Mise en Valeur; Report, 77 SGN 433 GTH; Bureau de Recherches Géologiques et Minières (BRGM): Orléans, France, 1977.

24. Lopez, S.; Hamm, V.; Le Brun, M.; Schaper, L.; Boissier, F.; Cotiche, C.; Giuglaris, E. 40 years of Dogger aquifer management in Ile-de-France, Paris Basin, France. Geothermics 2010, 39, 339-356. [CrossRef]

25. Muffler, P. Assessment of Geothermal Resources of the United States-1978; Geological Survey Circular 790; United States Geological Survey (USGS): Arlington, VA, USA, 1979.

26. Williams, C.F.; Reed, M.J.; Mariner, R.H. A Review of Methods Applied by the U.S. Geological Survey in the Assessment of Identified Geothermal Resources (01961497); United States Geological Survey (USGS): Reston, VA, USA, 2008. Available online: http:/ / pubs.usgs.gov/of/2008/1296/ (accessed on 10 November 2017).

27. Williams, C.F.; Reed, M.J.; Mariner, R.H.; DeAngelo, J.; Galanis, S.P., Jr. Assessment of Moderate- and High-Temperature Geothermal Resources of the United States (23276916); United States Geological Survey (USGS): Menlo Park, CA, USA, 2008. Available online: http:/ / pubs.usgs.gov/fs/2008/3082/ (accessed on 10 November 2017).

28. Garg, S.G.; Combs, J. A reformulation of USGS volumetric "heat in place" resource estimation method. Geothermics 2015, 55, 150-158. [CrossRef]

29. Bolton, R.S. Management of a geothermal field. In Geothermal Energy-Review of Research and Development; Armstead, H.C.H., Ed.; The United Nations Educational, Scientific and Cultural Organization (UNESCO): Paris, France, 1973; pp. 175-184.

30. Nathenson, M. Physical Factors Determining the Fraction of Stored Energy Recoverable from Hydrothermal Convection Systems and Conduction-Dominated Areas; Open-File Rept. 75-525; U.S. Geological Survey: Menlo Park, CA, USA, 1975.

31. Hurter, S.; Schellschmidt, R. Atlas of geothermal resources in Europe. Geothermics 2003, 32, 779-787. [CrossRef]

32. Williams, C. Evaluating the volume method in the assessment of identified geothermal resources. Geotherm. Resour. Counc. Trans. 2014, 38, 967-974.

33. Bödvarsson, G. Report on the Hengill geothermal area. Tímarit V.F.I. (J. Icel. Eng. Soc.) 1951, 36, 1-48.

34. Bödvarsson, G. An appraisal of the potentialities of geothermal resources in Iceland. In Proceedings of the 6th World Power Conference, Melbourne, Australia, 20-27 October 1962. Paper 206.

35. Bödvarsson, G. An estimate of the natural heat resources in a thermal area in Iceland. Geothermics 1970, 2, 1289-1293. [CrossRef]

36. Gringarten, A.C.; Witherspoon, P.A.; Ohnishi, Y. Theory of heat extraction from fractured hot dry rock. J. Geophys. Res. 1975, 80, 1120-1124. [CrossRef]

37. Wunder, R.; Murphy, H. Thermal Drawdown and Recovery of Singly and Multiply Fractured Hot Dry Rock Reservoirs; NASA STI/Recon Technical Report N; Los Alamos Scientific Laboratory: Los Alamos, NM, USA, 1978.

38. Fox, D.B.; Sutter, D.; Beckers, K.F.; Lukawski, M.Z.; Koch, D.L.; Anderson, B.J.; Tester, J.W. Sustainable heat farming; modeling extraction and recovery in discretely fractured geothermal reservoirs. Geothermics 2013, 46, 42-54. [CrossRef]

39. Björnsson, G.; Bödvarsson, G. A survey of geothermal reservoir properties. Geothermics 1990, 19, 17-27. [CrossRef]

40. Mégel, T.; Rybach, L. Production capacity and sustainability of geothermal doublets. In Proceedings of the World Geothermal Congress, Kyushu-Tohoku, Japan, 28 May-10 June 2000.

41. Rybach, L. Geothermal Energy: Sustainability and the Environment. Geothermics 2003, 32, 463-470. [CrossRef] 
42. Bödvarsson, G. Geothermal resource energetics. Geothermics 1974, 3, 83-92. [CrossRef]

43. Kühne, K.; Maul, A.-A.; Gorling, L. Aufbau eines Fachinformationssystems Geophysik. Z. Angew. Geol. 2003, 2, 48-53.

44. Schulz, R.; Werner, K.H. Einfache Korrekturverfahren für Temperaturmessungen; Report, Archive Number 99 914; Niedersächsisches Landesamt für Bodenforschung-Geowissenschaftliche Gemeinschaftsaufgaben (NLfB-GGA): Hannover, Germany, 1987.

45. Agemar, T.; Schellschmidt, R.; Schulz, R. Subsurface temperature distribution in Germany. Geothermics 2012, 44, 65-77. [CrossRef]

46. Ganz, B.; Thomas, R. Verbundprojekt GEOFÜND: Charakterisierung und Weiterentwicklung Integrativer Untersuchungsmethoden zur Quantifizierung des Fündigkeitsrisikos-Teilprojekt B: Optimierung der Methode auf der Grundlage von geowissenschaftlichen Daten und Informationen; Final Report, Archive Number 0133433; Leibniz Institute for Applied Geophysics (LIAG): Hannover, Germany, 2012.

47. Kuder, J. Berechnung von T/H-Werten und Konstruktion von T/H-Zonen für Geothermisch Relevante Schichten in Nordostdeutschland; Report, Archive Number 0130617; Leibniz Institute for Applied Geophysics (LIAG): Hannover, Germany, 2012.

48. Kunkel, C.; Agemar, T.; Moeck, I. Hydraulische Eigenschaften und diagenetische Änderungen geothermischer Reservoire in NW-Deutschland. In Proceedings of the Der Geothermiekongress 2017, Munich, Germany, 12-14 September 2017.

49. Birner, J. Hydrogeologisches Modell des Malmaquifers im Süddeutschen Molassebecken. Ph.D. Thesis, Free University of Berlin, Berlin, Germany, 7 June 2013. Available online: http:/ / www.diss.fu-berlin.de/diss / receive/FUDISS_thesis_000000094628 (accessed on 30 January 2018).

(C) 2018 by the authors. Licensee MDPI, Basel, Switzerland. This article is an open access article distributed under the terms and conditions of the Creative Commons Attribution (CC BY) license (http:/ / creativecommons.org/licenses/by/4.0/). 